Acta Oto-Laryngologica

\title{
Secondary Suture after Simple Mastoid Operation
}

\section{Professor Holger Mygind}

To cite this article: Professor Holger Mygind (1921) Secondary Suture after Simple Mastoid Operation, Acta Oto-Laryngologica, 3:1, 92-93, DOI: 10.3109/00016482109121171

To link to this article: http://dx.doi.org/10.3109/00016482109121171

\section{曲 Published online: 08 Jul 2009.}

Submit your article to this journal $\pi$

Џll Article views: 1

Q View related articles $₫$ 


\title{
Secondary Suture after Simple Mastoid Operation.
}

\author{
By Professor HOLGER MYGIND, \\ Copenhagen.
}

At the First Northern Oto-Laryngological Congress, in 1911, I gave publicity for the first time to my method for shortening, the after-treatment after simple mastoid operation by applying secondary suture over a fresh bloodclot in the wound cavity of the bone. I then had 62 cases at my disposal. At the Congress of 1914, I recommended the method once more, having then used it in 162 cases in all, and I could then report primary recovery in about $3 / 4$ of those cases, whereas originally I had only reached it in $2 / 3$.

To-day I should like to present the results of 151 fresh cases thus disposing over 313 cases in all at the present time.

Of these 151 new operations, 22 were bi-lateral, and my material thus comprises 140 individuals.

Among the 140 patients operated upon, 55, i.e. $40 \%$, were grown up, and 85 , i.e. $60 \%$, children. These numbers correspond exactly to the whole number of patients on which resection of the mastoid process has been performed at the Clinic of the Kommunehospital.

As for the results, suppuration of the bloodclot took place in 29 of the 151 mentioned cases of secondary suture, i. e. $19 \%$ -thus a still better result than in the two earlier series.

Among the cases that went off successfully there yet were a small number $-9 \%$ of the operations in all-where there occurred slight ruptures of the epidermis surface or local suppuration round the Michel clamps whereby the primary healing was deferred a few days. 
The oldest patient with whom there was healing per primam was 81 years, the youngest 2 months old, and age on the whole is of no consequence as a reason for the success or failure of the operation.

The kind of bacteria, on the other hand, is of great significance, as it is shown that in about $30 \%$ of the cases where streptococci were found at the operation the bloodclot eventually suppurated, whereas this only happened in about $10 \%$ of the cases where other bacteria were present.

The condition of the skin also has great influence; it is therefore important not to make a secondary suture before all infiltration of the soft parts has disappeared, eczematous changes healed, and so on. The circumstance that there has been a subperiostal abscess is not a sufficient counter-indication for applying a secondary suture, and the percentage of recoveries for this kind of cases is not considerably smaller than for the others.

The circumstance that will easiest risk the result-as far as this material is concerned, in about $1 / 2$ the number of casesis a recurrence of the suppuration of the middle-ean, which will arise specially when the secondary suture is repeated before the drumbead perforation is healed.

In many of the cases where there is a suppuration of the bloodclot, the after-treatment will none the less be shortened, the wound cavity being reduced in size, the skin edges better drawn together, without getting entangled into the wound, \&c.

As for the technique and the indications, I refer to my earlier communications. I only want to add that I have lately used local anaesthesia for grown people with excellent result. 